Document downloaded from:

http://hdl.handle.net/10251/100067

This paper must be cited as:

Vegas López-Manzanares, F.; Mileto ., C.; Cristini ., V. (2014). Constructive features and preservation work of rammed earth architecture:

the Islamic tower of Bofilla (Valencia). Journal of Architectural Conservation. 20(1):28-42. doi:10.1080/13556207.2014.886377

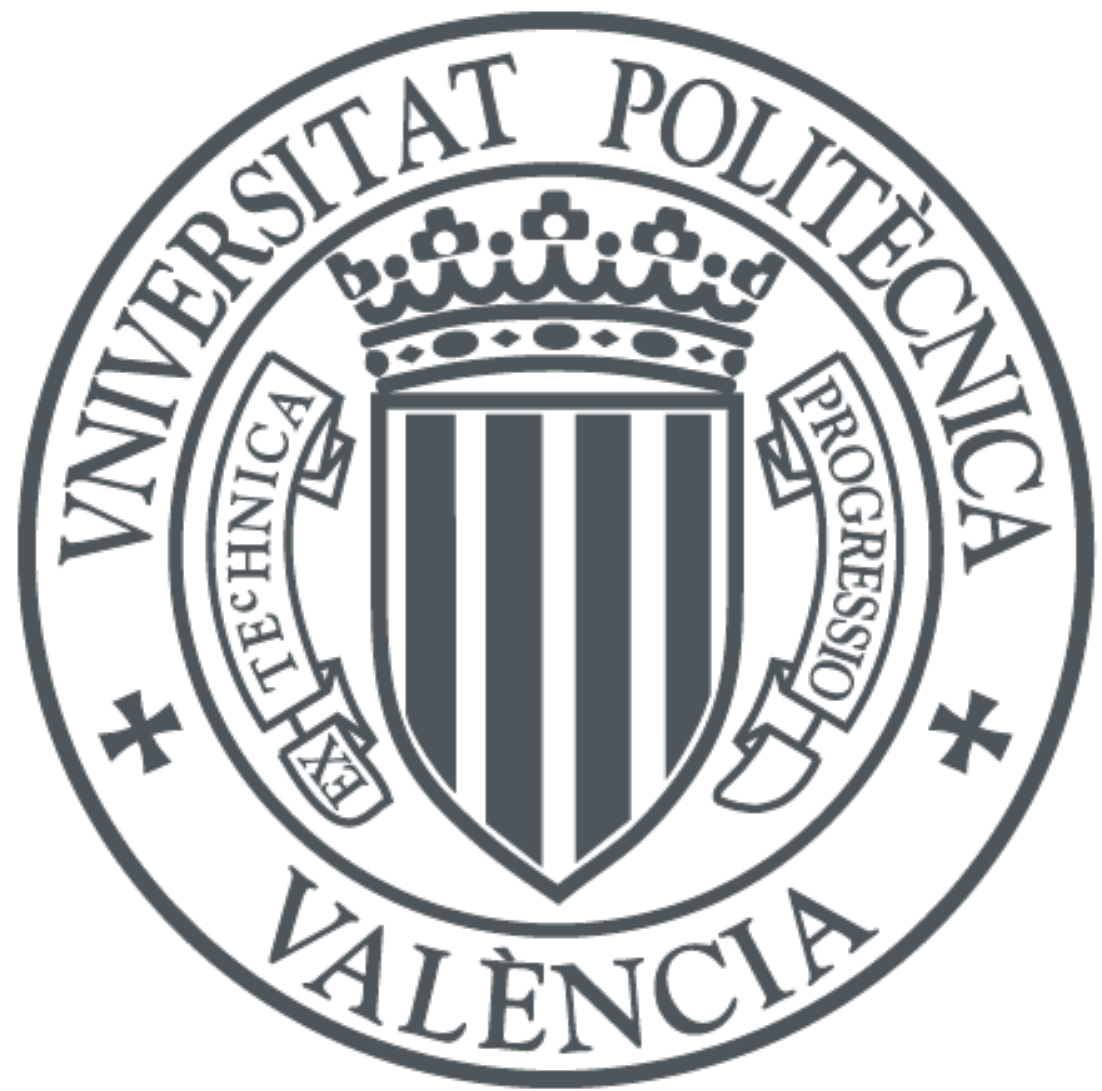

The final publication is available at

https://doi.org/110.1080/13556207.2014.886377

Copyright Taylor \& Francis

Additional Information 


\title{
Constructive features and preservation work of rammed earth architecture: the Islamic tower of Bofilla (Valencia)
}

\author{
F. Vegas, C. Mileto* and V. Cristini \\ Departamento de Composición Arquitectónica, Instituto de Restauración del Patrimonio, Universitat \\ Politècnica of Valencia (Spain), Valencia, Spain
}

\begin{abstract}
The Bofilla tower (Valencia, Spain), at 800 years old one of the oldest buildings still standing in the whole region, is a rubble-reinforced rammed earth construction almost $20 \mathrm{~m}$ high. Its precarious condition called for preservation works and the enhancement of the surrounding archaeological site. However, these works involved a serious risk that the original construction might lose its hallmarks and its history, which had great narrative potential, due to the plasticity of the earth. Furthermore, as often happens, a great deal of the character and antiquity of the tower were linked to the erosion and abrasion of its rammed earth surfaces, so it was necessary for the preservation to try to alleviate or stop the degradation that threatened the tower's survival and, at the same time, conserve its narrative potential, its aura and its ancestral character. After performing a comprehensive preliminary study of the construction and its state of repair, a large number of preservation tasks were carried out, from cleaning the façades by hand to reconstructing the structure of the tower in several spots, such as the south-western corner and, especially, the entrance in the northern façade, which was on the verge of collapse. Other operations included filling in the lacunae in the fabric both inside and outside the tower, micro-pointing the rubble filling in the most degraded areas of the southern façade and protecting and consolidating the crowning. In addition, new floors and a staircase leading up to the top of the tower were inserted in the places where their traces were still visible to avoid damaging the fabrics and to perform the most faithful archaeological reconstruction possible. The article addresses the study, reflections and technical operations carried out on the tower during the works on site, with the objective of maintaining the original materiality of the rammed earth fabric and the traces of its construction and life as a testimony of its history.
\end{abstract}

Keywords: earthen buildings; Islamic architecture; preservation criteria

\section{The rammed earth technique}

Rammed earth is a building technique that consists of compacting in a formwork successive courses of earth as the main material, with the eventual addition of other materials or binders, such as lime, gypsum, stone filling, bricks, gravel, etc. There are many historic variants of this technique because of different functional needs and the differing availability of materials in each area. Within Europe there is an outstanding presence of this technique in the Pannonian plain, in the Rhone-Alps region in France, in the Piedmont region in Italy and, above all, in the Iberian Peninsula, where there exists a great number of variations of this technique (rammed earth, gypsum-reinforced rammed earth, lime-crusted rammed earth, rammed earth with reinforced joints, brick-reinforced rammed earth, etc.). ${ }^{1}$ This technique was used as early as the Roman era, according to the testimony of Pliny and Vitruvius. However, under the

*Corresponding author. Email: cami2@cpa.upv.es 
Muslim dominion (eighth-fifteenth century) it gained a leading role, particularly in the building of fortifications.

\section{Watchtowers in Levant}

During Islamic dominion (711-1238), the city of Valencia (Spain) had a strategic belt of fortified watchtowers that allowed lookouts to spot Christian raids or razzias early enough to let inhabitants of the settlements by the tower take refuge in it. The building of this ensemble of 30 towers emerged from the surprising temporary conquest of the city by Cid Campeador (1094-1099) and was accelerated at the beginning of the thirteenth century, as the Christian kingdom was advancing its positions from the north and threatened a definite conquest of the city (Figure 1). ${ }^{2}$

These towers were typically associated with rural settlements in the countryside. As was commonly the case for Islamic military architecture in the Iberian Peninsula, the building technique used to erect these towers was rammed earth enriched with lime and internal stone filling (Figure 2). Their extraordinary longevity, of over 800 years, is irrefutable evidence of the great quality of execution of the 20 towers still standing at present. $^{3}$ All around $20 \mathrm{~m}$ high, they are still standing despite the fact that they have been at times ignored and consistently exposed to weather damage over the past five centuries.

During the past 30 years, many of these towers made out of rammed earth have been reconstructed, with diverse results, according to the criteria of the architects in charge. Often, and independently from their more or less damaged condition, they have undergone a process of total replastering of all surfaces, which has eliminated traces accumulated upon the building stage and also the patina. Pursuing the recovery of the original profile and the volume of the fortifications,

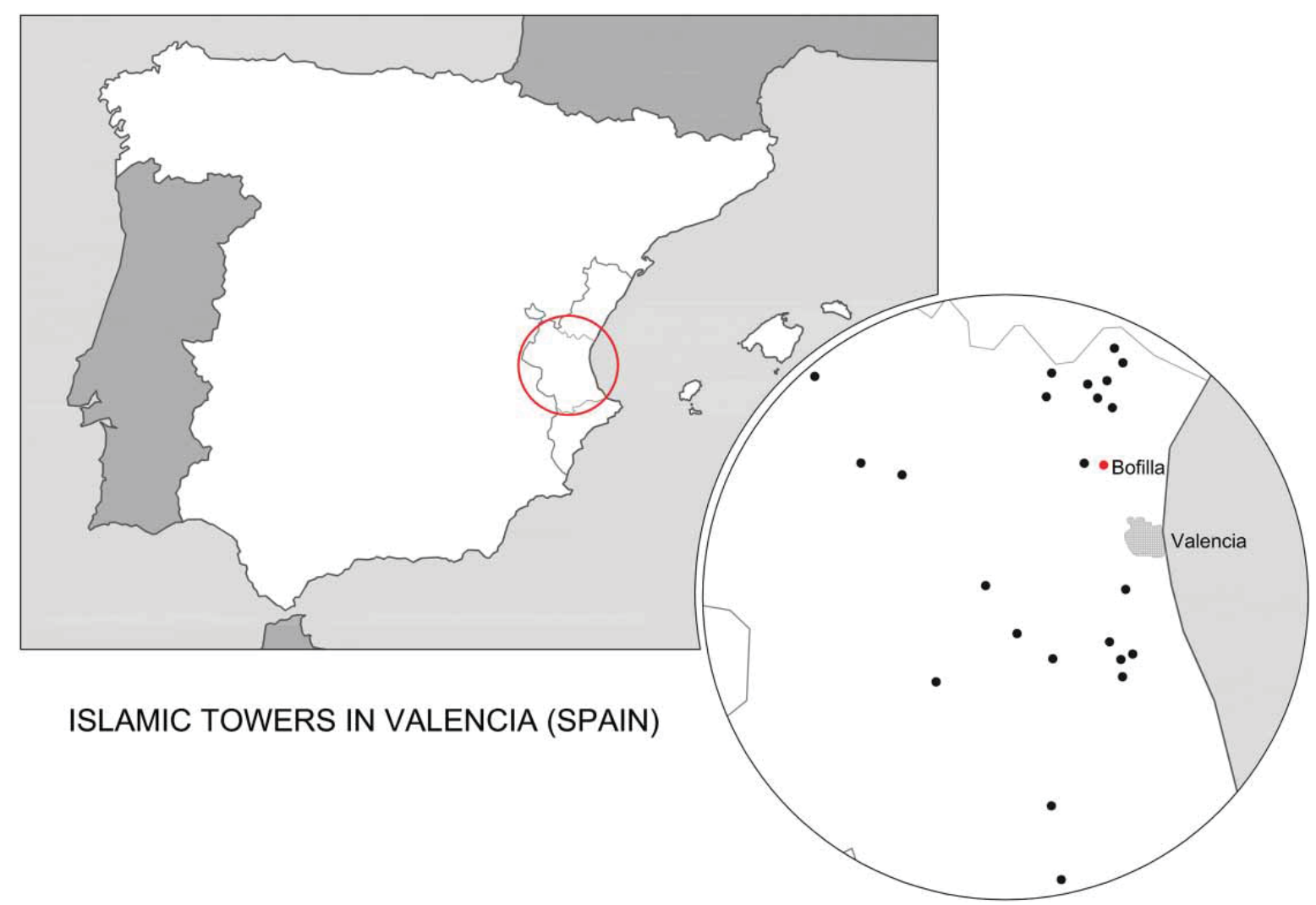

Figure 1. Location map of the Islamic tower of Bofilla surrounded by other similar towers near the city of Valencia (Spain). (Vegas \& Mileto) 

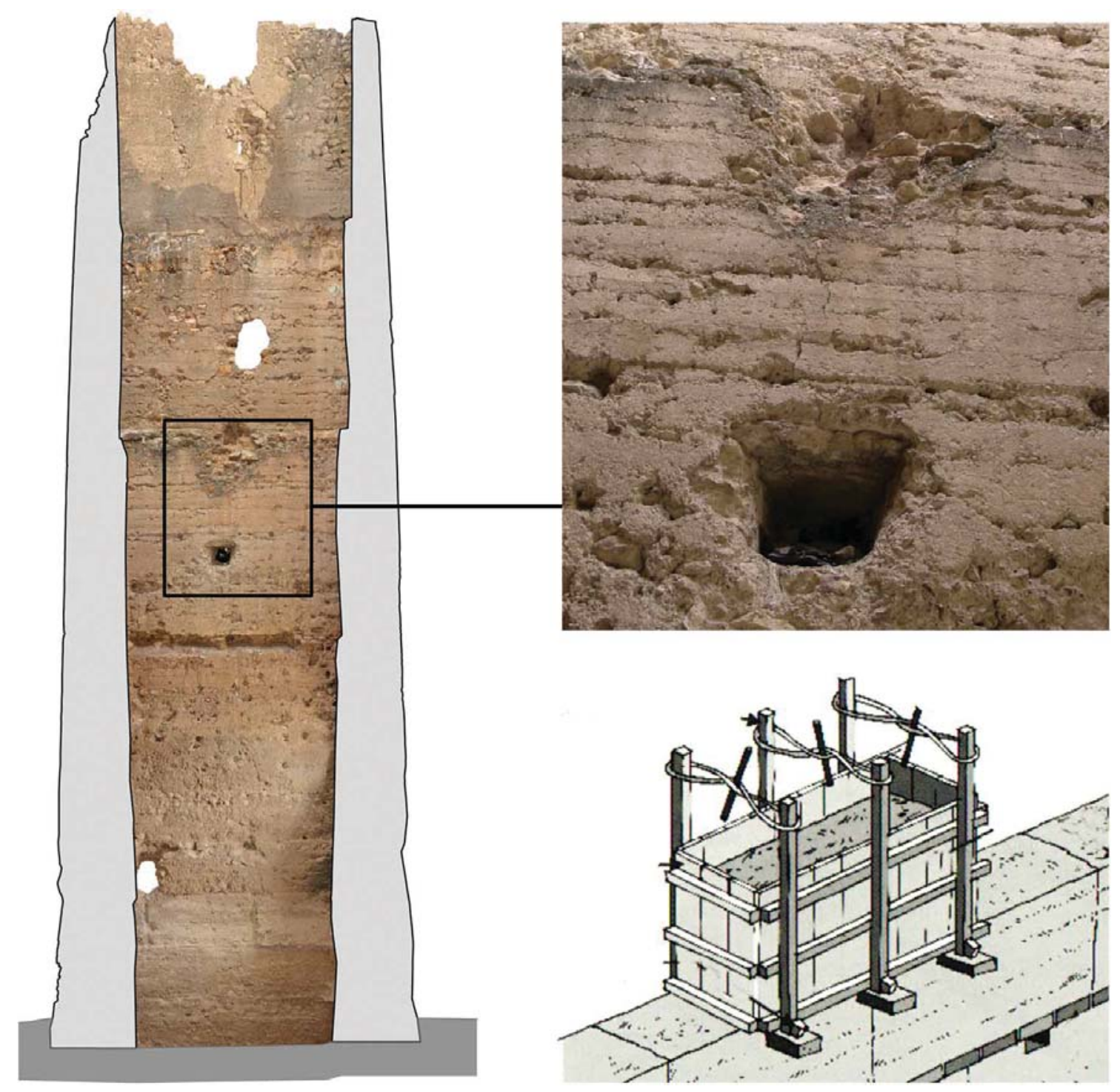

Figure 2. Detail of the masonry of watchtowers: rammed earth walls enriched with lime and internal stone filling (Vegas \& Mileto).

over other considerations, has also lessened the antiquity and authenticity values of the old fabrics. Other examples of these kinds of interventions are the tower of Bétera castle, the tower of Albal and the tower of Almussafes.

Bétera is a unique town in the peripheral area of Valencia that has two Islamic rammed earth towers: the castle tower and the Bofilla tower. With all traces of the historical building work of the castle tower lost due to its total re-plastering, the preservation of the Bofilla tower, of which we were in charge, was the town's last opportunity to preserve a rich historical token of its past and safeguard it for the future. Additionally, the archaeological excavations carried out on the settlement by the tower in the 1980 s were badly in need of repair before visitors could access the site.

\section{The Bofilla tower: description}

Given the lack of documentation about the building, before the previous study regarding the preservation of the Bofilla tower in Bétera it was presumed that the tower had been erected during the twelfth century, associated with a surrounding village (Figure 3). The tower was used by Islamic settlers up to 1238, the year of the Christian Reconquista of Valencia. After this it was used by 


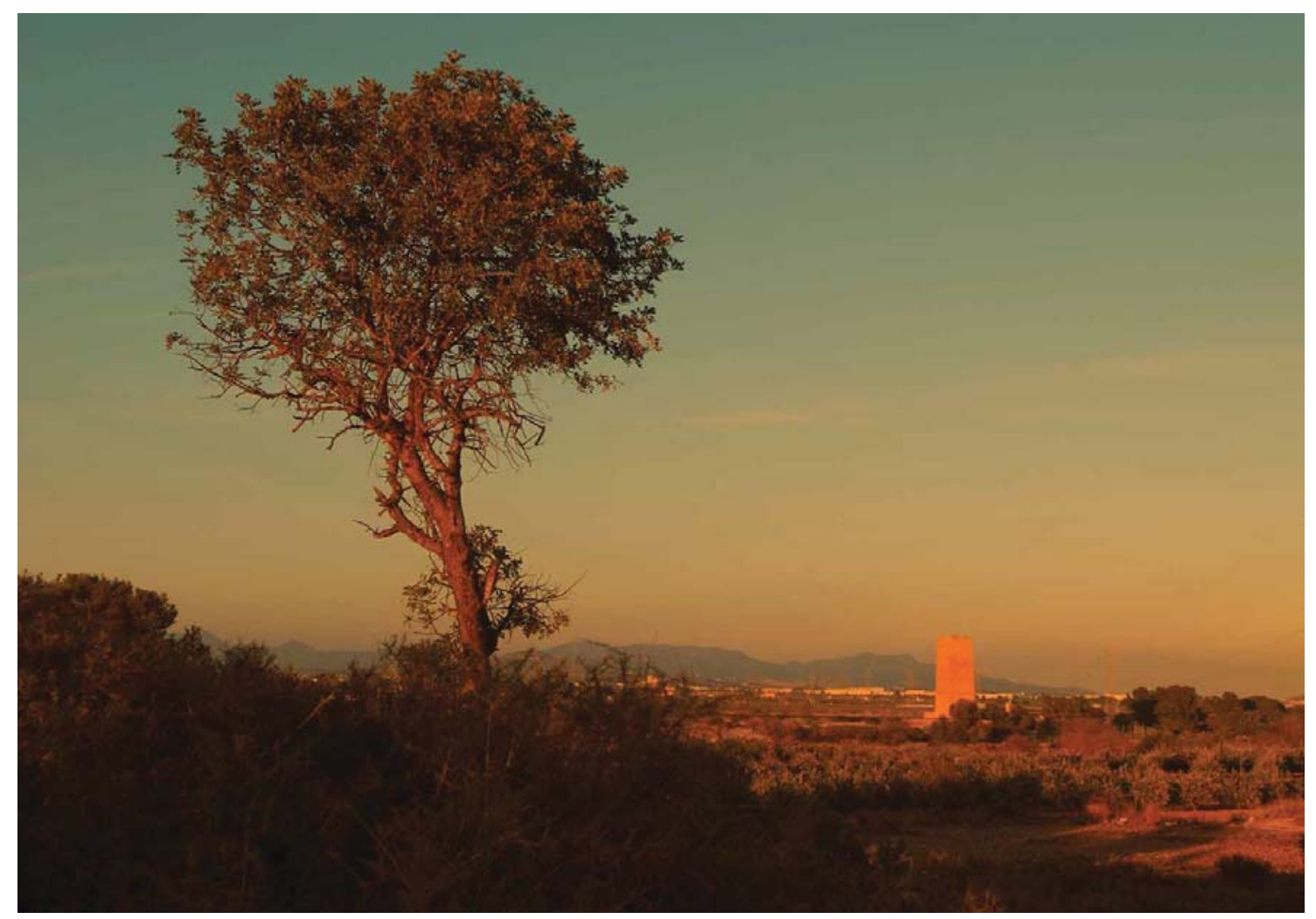

Figure 3. Bofilla tower and its surroundings (Vegas \& Mileto).

the new Christian dwellers, particularly during the wars against the Kingdom of Castilla. ${ }^{4}$ In the fifteenth century, when the kingdoms of Castilla and Aragon became a single kingdom and the geographic borders of Spain were finally settled, threats in the internal territory disappeared, meaning the tower's main use was lost and it was gradually abandoned. It was probably after this that it lost its internal wooden floors as a result of a fire.

The tower has a square $6.15 \mathrm{~m}$ by $6.15 \mathrm{~m}$ plan at the base that is gradually reduced following the profile of a truncated pyramid, reaching $5.20 \mathrm{~m}$ at the coping of the building. The thickness of the walls is over $1.20 \mathrm{~m}$ at the base and $56 \mathrm{~cm}$ at the top of the tower. It has a total of 21 rammed earth courses with heights ranging between 83 and $92 \mathrm{~cm}$, whose addition results in a total magnitude of $18 \mathrm{~m}$. The main raw material of the tower is local earth mixed with $10 \%$ lime. During the excavation works and processing of archaeological remains partially discovered in the past, the kiln that made the lime used in the building of the tower was found. ${ }^{5}$ To erect the tower, stone filling was used, arranged in order inside the formwork in each ramming stratum previous to its compacting, with the double objective of avoiding excessive use of earth and lime while at the same time strengthening the walls.

The plasticity of the earth walls and its capability to show the prints of the actions carried out on them has allowed us to discover not only the traces of the formwork formed by five individual boards in the interior and exterior sides, together with the formwork putlogs, but also the traces of the portal and wooden floors, whose remains have now vanished (Figure 4). Access to the tower was through the northern façade by means of a double arch of ashlar stones levelled to the external and internal parts respectively, from which only five stone voussoirs remain on one of the external sides, together with the negative stamps of their existence in the internal parameter. The location of the original stairs can be assumed from the absence of holes of the floor logs in some sections of the walls. 

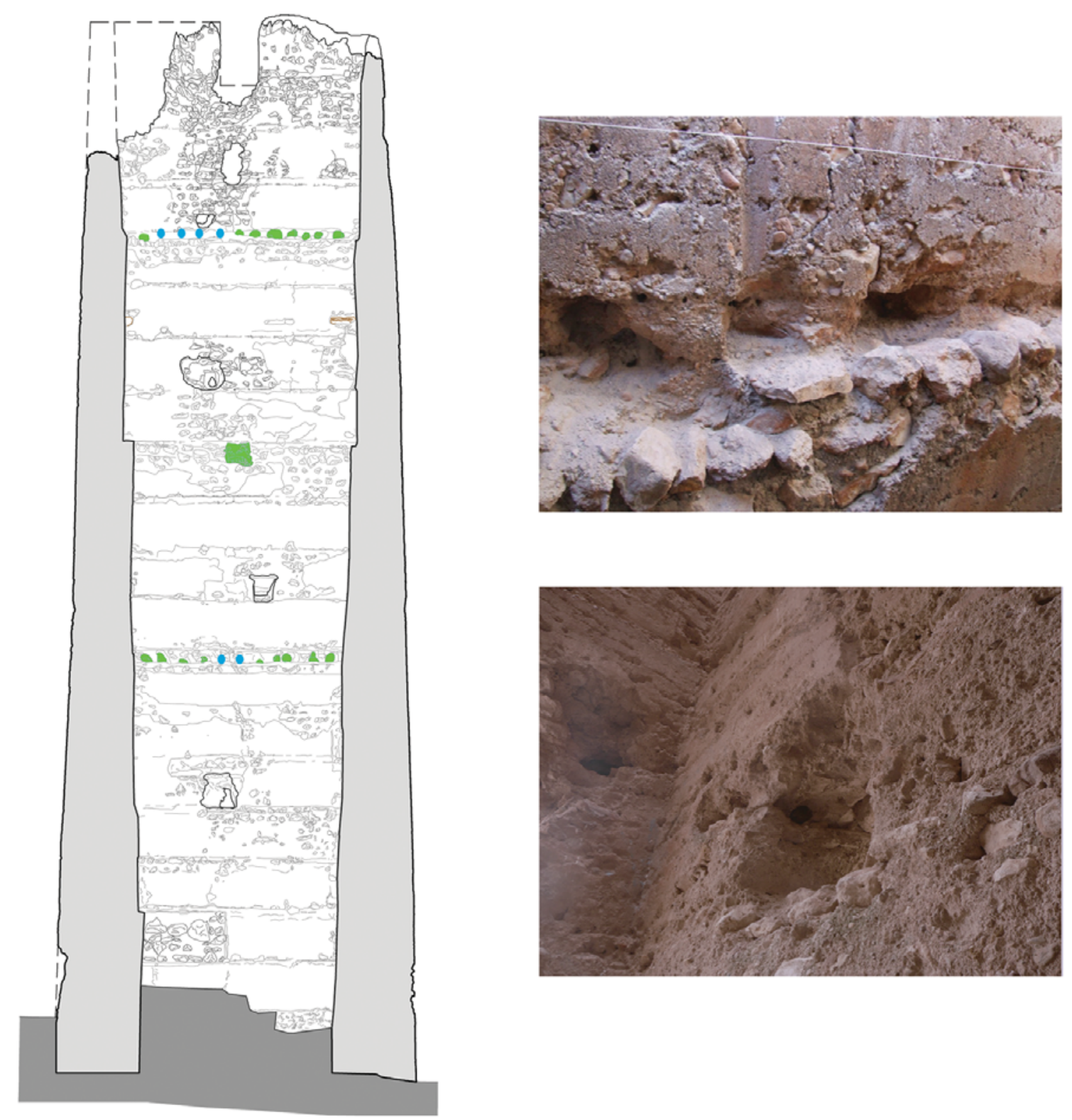

Figure 4. Prints of the wooden floors, whose last remains had vanished (Vegas \& Mileto).

Additionally, it is known that the floors were formed from a large beam of $22 \mathrm{~cm}$ in diameter and many crossed joists of 14-15 cm arranged next to each other, all of them slightly shaped logs. The tower used to have three floors of these characteristics, separated by four rammed earth courses, and a parapet walk at the top level, built over two large beams and crossed joists of smaller size, three rammed earth modules higher than the level underneath. The beams reached the external side, creating a cantilever at both fronts in order to form machicolations. Two special joists were placed perpendicular to these two beams, probably nailed to them to provide two further machicolations at the other two fronts.

\section{Peculiarities of the building of the Bofilla Tower}

According to the result of the carbon 14 test performed on the timbers preserved in the interior of the tower and the ceramic pieces found in the filling at its base, one can confirm with relative certainty that the tower was erected between 1210 and 1220, probably as a result of Pedro II's 
conquest of the nearby region of Rincon de Ademuz in August 1210, which predicted imminent danger for the Islamic kingdom of Valencia.

In fact, study of the tower has allowed the presumption that the building work of this tower was carried out in a hurry, even using some improvised means, and was perhaps developed at the hands of the same inhabitants of the neighbouring Islamic village. This would also correspond to the use of home-made formworks, probably those used for the building of the village family houses, joined to each other, but not reaching the sufficient length to make up the complete perimeter of the tower.

This circumstance demanded the construction of two sectors with a U-shape per each rammed earth course, alternating this discontinuity in height required turning the U-shaped modules in order to avoid vertical discontinuity at the front (Figure 5). In this way the joints, with their typical $60^{\circ}$ incline, were alternated in the successive courses of the tower, excluding some exceptions in which two and even three courses were built one after the other in vertical continuity.

As will be seen, these consecutive joints suffered deeper damage after the disappearance of the entrance portal made of ashlars on the tower's northern façade. It would have been very useful to bond these discontinuities with some wooden ties embedded in the rammed earth, as is the case at other points of the tower, given that this prevention would have avoided some of its present pathologies.

Another important aspect of the building work lies in the eventual employment of light gravel, in the shape of olive stones mixed with the mass of rammed earth at the top section of the tower. Even though it is difficult to state for sure, the presence of olive stones mixed into the mass of the
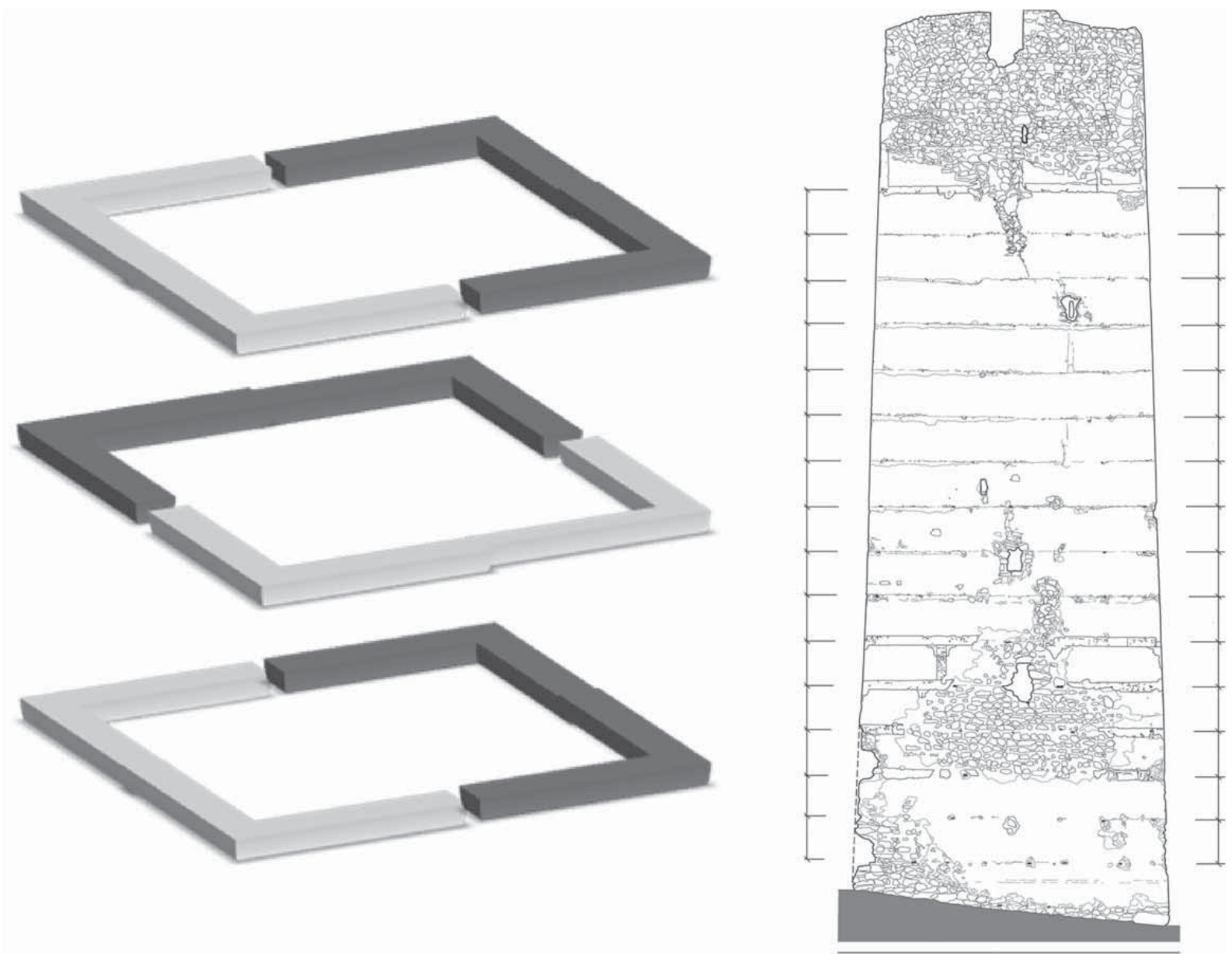

Figure 5. U-shape construction section alternated per each rammed earth course (Vegas \& Mileto). 
rammed earth allows the presumption that it was done intentionally. Olive stones were used up to recent times as light gravel for compressive layers of reinforced concrete in areas of great olive oil production, such as the province of Jaén.

\section{Why Bofilla Tower still stands after 800 years}

The endurance of these towers in general, and in particular the survival of Bofilla tower throughout this long period of time - especially given the past five centuries of neglect - is due to a number of reasons: ${ }^{6}$

- Protection against dampness. The settlement of the tower on the top of a hill prevents rain water from accumulating as it is easily expelled towards the environs. Furthermore, according to the building tradition of rammed earth in many places, the putlogs and joints in the rammed earth were sealed by $15 \mathrm{~cm}$-large strips rendered with mortar rich in lime and applied al fresco, with a 1:1 proportion of lime/gravel, which served at once as protection and as decoration, having the appearance of false ashlars. The parapet in the coping was completely plastered with the same mortar.

- Addition of binder to the earth. The use of rammed earth with addition of $10 \%$ lime to the mass - even though it is not a large quantity in relative terms - generated sufficient protection of the parameter's surface. ${ }^{7}$ In fact, during the process of ramming of the earth layer, the lime and finest gravel experience a process of migration to the timbers of the formwork, creating a smooth and compact surface that resists outside inclemency.

- Tower design. The erection of the tower in a truncated pyramid shape confers greater stability to the ensemble, with walls whose thickness is over $160 \mathrm{~cm}$ at the base, becoming thinner and sloped in the external part and with two successive staggerings coincident with the second and third floors inside. The walls finish at a thickness of $56 \mathrm{~cm}$ at the coping of the tower.

- Implosive geometry of the earth strata compacted inside the floor, according to which they are not completely horizontal but are slightly depressed at the centre of each of the parameters, creating an effect of pre-compression to the inner part of the tower. This feature, together with its truncated pyramid shape, confers more stability to the building.

- Layout of wooden floors. The arrangement of the three interior floors and the parapet walkalternating the position of the joists successively - contributes to tie together the tower walls in both directions, avoiding the weakening of two fronts in relation to the adjacent ones. This alternated placement also made easier the use of ladders in order to access it, as they could lean on a horizontal plan on each floor and not on the void of the lower floor.

- Continuity and reinforcement of corners. The building avoided the creation of joints at the corners of the tower, which are both difficult to make and a weak point from the viewpoints of construction and defence. It was mentioned previously that despite the lack of a continuous formwork for the tower perimeter, the corners were formed in a continuum and the joints were arranged in the centre of the parameters. Moreover, the corners were reinforced with wooden ties inserted in each rammed earth course.

- Choice of wood type. The kind of wood chosen for the building was olive tree wood. ${ }^{8}$ After the initial surprise at the results of the wood analysis, later research unveiled that without pruning, wild olive trees can grow up to $8 \mathrm{~m}$ in height and can produce logs and branches which, even though they are irregular, are good for building purposes. The medieval olive tradition was to allow the olive trees to grow wild and reach their natural height. In this way, the underlying terrain could be used for other crops or for cattle ranging. Olives were not 
collected by beating the trees with poles, as is the case nowadays; they were gathered from the ground after falling from the trees. In a treatise, Vitruvius recommended the use of superficially scorched olive wood for building purposes because of its great durability and resistance to the attacks of xylophage insects. There are more examples of the use of olive wood in other Islamic buildings in other parts of Spain. The wood could not survive the fire that destroyed the inside wooden floors; however, its durability has enabled the survival of lintels of the embrasures and the wooden ties of the construction, which continue to carry out their duty 800 years on.

\section{The tower pathologies}

While it was in a nearly complete state, the tower was in a precarious condition (Figure 6), translated into the following phenomena: ${ }^{9}$

- General erosion of the bottom and top parts of the southern wall of the tower, where stone fillings from the interior mass appeared in the eroded surface.

- The existence of a large access hole at the south-eastern corner, with dimensions great enough for a man to get through. It also allowed access to the first level of the tower, placed at four rammed earth courses, or $3.60 \mathrm{~m}$, from the land.

- Disappearance of the ashlars portal, which caused the partial collapse of the interior vertical parameter to the point of the coping of the building and a large breach on the external side.

- Disappearance of the historic wooden floors, parapet walls and machicolations, from which there are some remains inside the openings held by the earth mass, which are evidence of their genuine character, coetaneous to the erection of the tower.

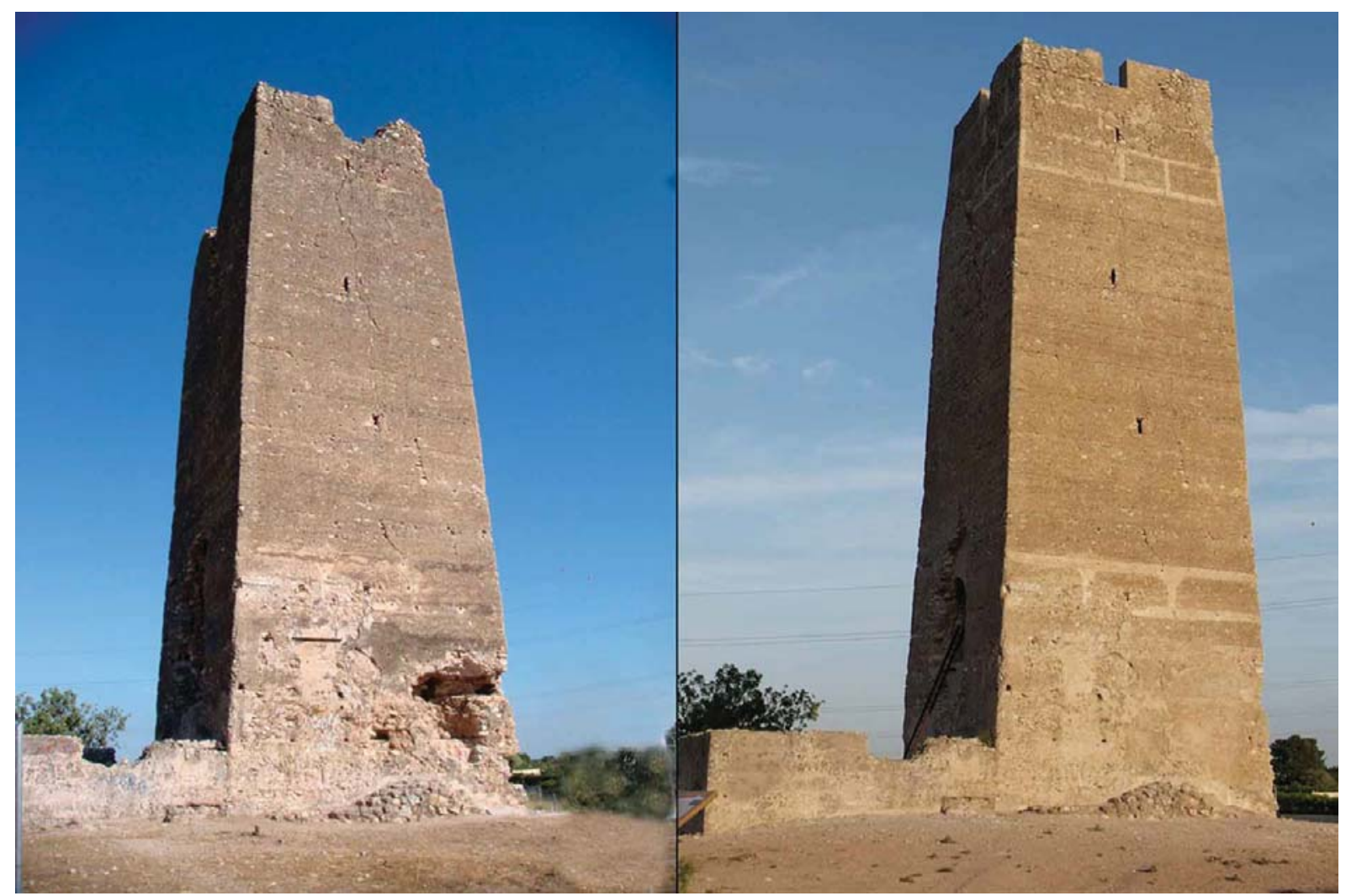

Figure 6. The tower, after and before preservation works (Cristini). 
- Major degradation of the coping of the tower, with the appearance of eroded crests and collapsed sections, particularly on the northern façade, over the entrance.

- Partial disappearance of the strips rendered with mortar rich in lime, as a result of erosion and putlog holes practised to accommodate some auxiliary construction, probably in the Christian age.

- Dirt and presence of lichens all over the surface of the four façades of the tower, especially on the northern and western walls.

Apart from the dirt and superficial erosion that would be expected of an 800 -year-old tower, one can see that the other pathologies suffered by the tower evolved directly from human actions, such as the pillage of the voussoirs from the double arch at the entrance, which provoked the partial collapse of the overlying fabrics, the opening of an access hole on the south-western corner, the creation of putlog holes to accommodate the floors of the adjacent constructions or the fire in the structure, which was probably intentional.

\section{Preservation criteria}

The preservation of rammed earth involves a series of important technical and conceptual problems with difficult solutions. ${ }^{10}$ The degradation and erosion of the surfaces show the antiquity value but, at the same time, can endanger the survival of the construction, in particular when they occur at the base of the building. For that reason, in any intervention to be developed for a rammed earth building, one must evaluate the extent to which reintegration of the lost mass is strictly necessary given that, as a consequence of this process, a large part of its authenticity vanishes. Reintegrations of lost mass in the rammed earth often have a major impact that distorts the historic building as a whole, because they are sometimes too large and, particularly, show the different finishes.

This is more obvious in the case of using the rammed earth technique in these reintegrations. The technique of forming and compacting the material comprising primarily earth has romantic connotations that often lead restorers to deem it logical to repair the rammed earth building using the same technique. However, the reintegration of missing parts and lacunae at the base or on the lateral wall are impossible with this technique, considering that the mix usually formed by poor materials and a small amount of binder acquires strength not because of the individual properties of the materials themselves, but because of the method of building by vertical compaction. These gaps' lateral reintegration with formwork, without the typical compaction or with an always complicated lateral compaction, does not offer a guarantee of long-term survival. On the contrary, the use of the rammed earth to rebuild the gaps at the top of the building, regardless of whether it can be justified and considered historically coherent, is possible if the formwork is adjusted to the coping of the building. ${ }^{11}$

However, both the almost impossible lateral reintegration with formwork or lateral compacting and the more feasible reintegration by means of formwork and top compacting generate an important issue: the contrast between a slightly eroded patina on the historic surface and the finish of a smooth and even surface that has just been stripped from the formwork. The only way to solve this contrast would be to artificially erode the new surface, but this intervention would initiate an unwanted process of degradation of the wall. The coherence sought by the use of the same original building technique raises a contradiction, a weakness in the building work and a visual disharmony, where the reintegrated shiny surfaces gain prominence over the historic building, contrary to the initial monument's preservation intent.

This distinguishability, as defended by Camillo Boito's restoration theory, ${ }^{12}$ does not however imply for these authors the need of a strong contrast between the existing parts and the added 


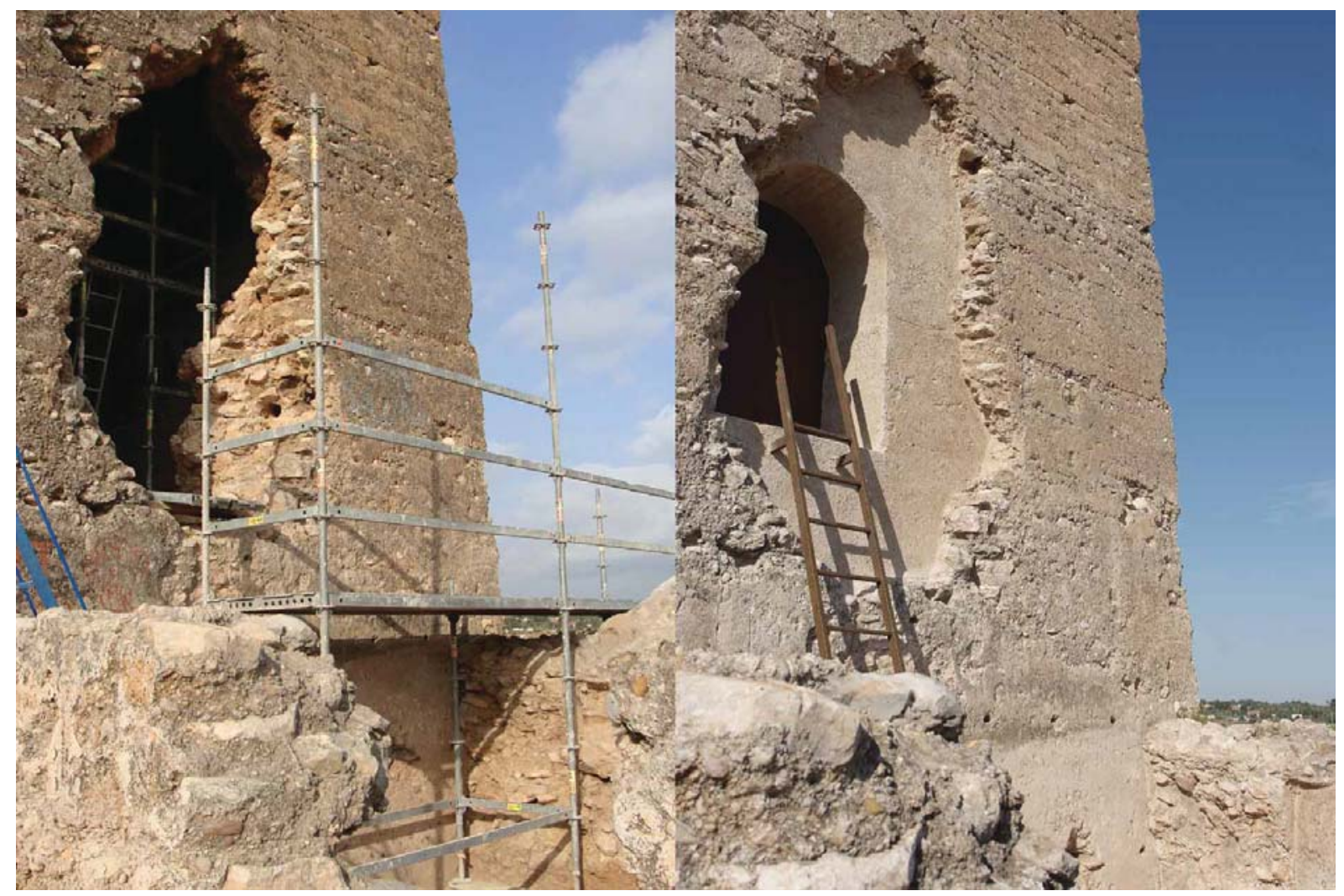

Figure 7. Reintegration works respecting the detail without having an impact on the overall view of the building (Cristini).

sections. Likewise, the reintegration of a historic painting by means of the rigattino technique manages to find harmony and visual completion from some distance, while allowing distinguishment of the reintegrated work at close inspection. The discipline of architectonic restoration can also respect the subtlety of the detail without having an impact on the overall view of the building (Figure 7). For all these reasons, we do not recommend the use of the historic technique of rammed earth in the reintegration of a rammed earth building even when the implementation of this technique could seem logical, interesting or exciting.

\section{Preservation works}

The preservation works started by cleaning the surfaces, which had been darkened by the presence of dirt and lichens. Different cleaning techniques were tested, with brushes of different sizes, various bristle materials and a range of detergent products of different intensity of application, always attempting to avoid abrasion of the original crust of the building. After developing various small tests for the cleaning, there emerged reflection about the degree of cleaning that was desired for the preservation of the tower. Deep cleaning would have completely changed the look of the tower and involved partial abrasion of the surfaces. Based on these considerations, the final decision was to clean the surfaces with soft bristle brushes and quaternary ammonium salts as the detergent agent (Figure 8).

Once the cleaning of all surfaces was completed, the missing parts were reintegrated observing the original colour, intonation and vibration of the historic surface. For that aim, hydraulic lime mortar was used, mixing Saint-Astier hydraulic lime NHL 3.5 with river gravel with heterometric characteristics in 1/3proportion. Given that the closest gravel to the original came from a quarry situated $300 \mathrm{~km}$ from the site, and considering the need to harmonize the reintegrated gaps 

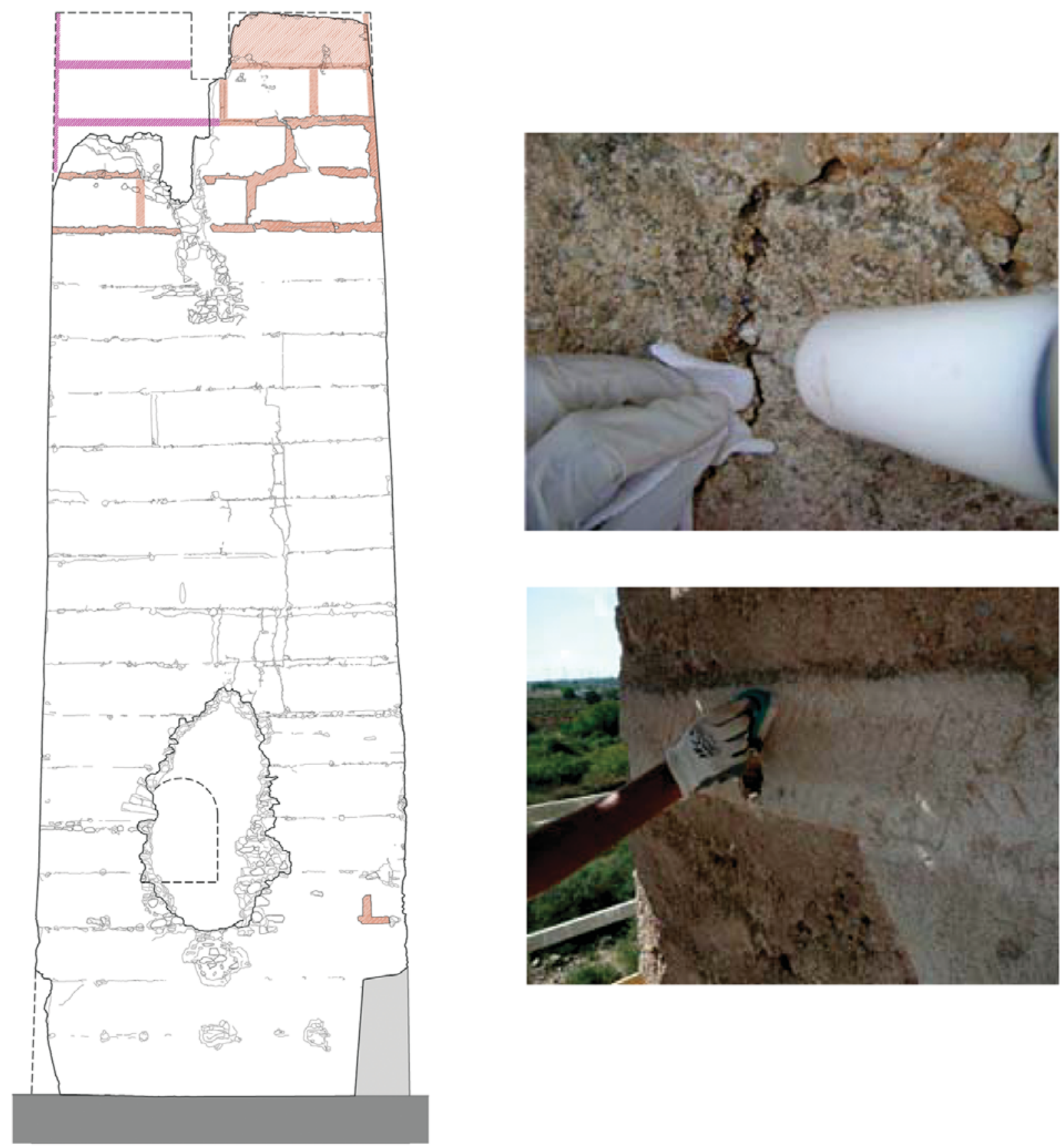

Figure 8. Examples of different consolidation and cleaning techniques (Vegas \& Mileto).

in their historic built context, we collected local gravel at the foot of the tower that was a result of the tower's erosion, collapse and partial losses, sieved it and mixed it with commercial gravel, using a third of local gravel with two thirds of commercial gravel so as to allow better integration of the missing parts with the vibration and chromatic range of the local gravel. Similarly, the mortar mass was slightly tinted with natural soils to shade the white colour of the lime, in order to bring it closer to the general colour of the cleaned tower surfaces. The tinting of the mortar mass did not attempt to match the average colour of the rest of the surfaces but to match the lightest shade observed in the historic fabric, in order to allow expert conservators to provide final harmonization of the finish by stencilling with natural soils mixed with lime.

The process of reintegrating gaps needed the insertion of stones arranged in order in the biggest hollows, placing them in successive historic layers at an approximate distance of $10 \mathrm{~cm}$ from the 
external surface. Later on, gaps were filled and thickly rendered, resulting in a final surface that was slightly recessed in relation to the overall surface. The final surface was brushed and cleaned several times with a sponge in order to eliminate the superficial binder and show the mortar gravel in favour of better integration. When the lacunae happened to be in between two courses of rammed earth, the process was done much in the same way, but the rendering stopped at the horizontal line between the courses. Some days later, the rendering work was resumed in such a way that the joints of the rendering - slightly printed but present - happened to meet those of the historic rammed earth construction. The reintegration of the lacunae aims at being contextual throughout the process, like the rigattino technique in a historic painting. Thus, observing the eventual appearance of the stone fillings and the thickness of the rendering, the textures, colours, shades, etc. have been worked on in varied ways, always according to the circumstances of the fabric surrounding the lacunae.

Sometimes the reintegration of volume was important, as in the case of the internal vertical breach on the northern façade. Prior to reintegrating the gaps, it was necessary to insert corrugated fibreglass rods to guarantee the connection of the historic fabrics and the added mass (Figure 9). The state of this particular area was so precarious that the rammed earth fabric needed to be drilled in order to insert the rods, always avoiding percussion, because that would cause the collapse of building materials and danger to the workers of the building company.

After long deliberation, the decision was made to partially rebuild the coping of the tower at the north-eastern corner, with a double aim of recovering the lost profile of the corner and bonding the crests of the eastern and northern façades, which were loose and about to collapse. However, it was decided to avoid completely rebuilding the edge of the corner, as in the case of the southeastern corner, erosion and lacunae did not involve danger of collapse. It was also decided to sharpen a brand new edge in the rebuilt area.

In some other generally eroded parts, where the stone filling appeared at the surface - as was the case in the lower and top parts of the southern side - the stone fillings were selectively repointed with 1:3 hydraulic lime mortar, with the objective of avoiding any rainwater accumulation on the top side of these stones and easing the expulsion of water.

In the internal part of the building, archaeological restitution of the floors was developed according to the existing traces in the tower, which expressed the original rhythm, number and location of the beams and joists. The possibility of using beams and joists of wild olive trees, as in the original construction, was not considered; nor was use of another type of wood with similar aspect to that of the wild olive trees, such as kermes oak wood - occasionally used in the vernacular architecture - given that, commercially speaking, it is not accessible nowadays and the objective of this reconstruction did not pursue the romantic idea of an impossible reproduction of the vernacular floors of Islamic manufacture. For all these reasons, the wood used to replace the original beams and joists was pine wood. Once the beams' and joists' heads were placed in the fabric, some internal anchorage was used to contribute to bracing of the ensemble. The beam filling of the original floor, made with branches and a $10 \mathrm{~cm}$-thick gypsum layer used as paving, was solved by a timber deck of $10 \mathrm{~cm}$ slats that contributes structurally to the underlying beams and joists in search of a higher monolithism. The perimeter of this deck was fastened by continuous angular metal separated from the walls, so that it bonds them while avoiding any damage to the rammed earth fabric.

Once the location of the ladder on each of the floors was discovered, and traces of its use as the only ladder used on each floor were found, a similar one was made. Unlike the historic arrangement, it was decided to create a fixed ladder for each floor in order to provide easier access for visitors, and also to support maintenance of the tower. The ladders were made by means of metal structures of tubular profile which were anchored to the floors and walls. 

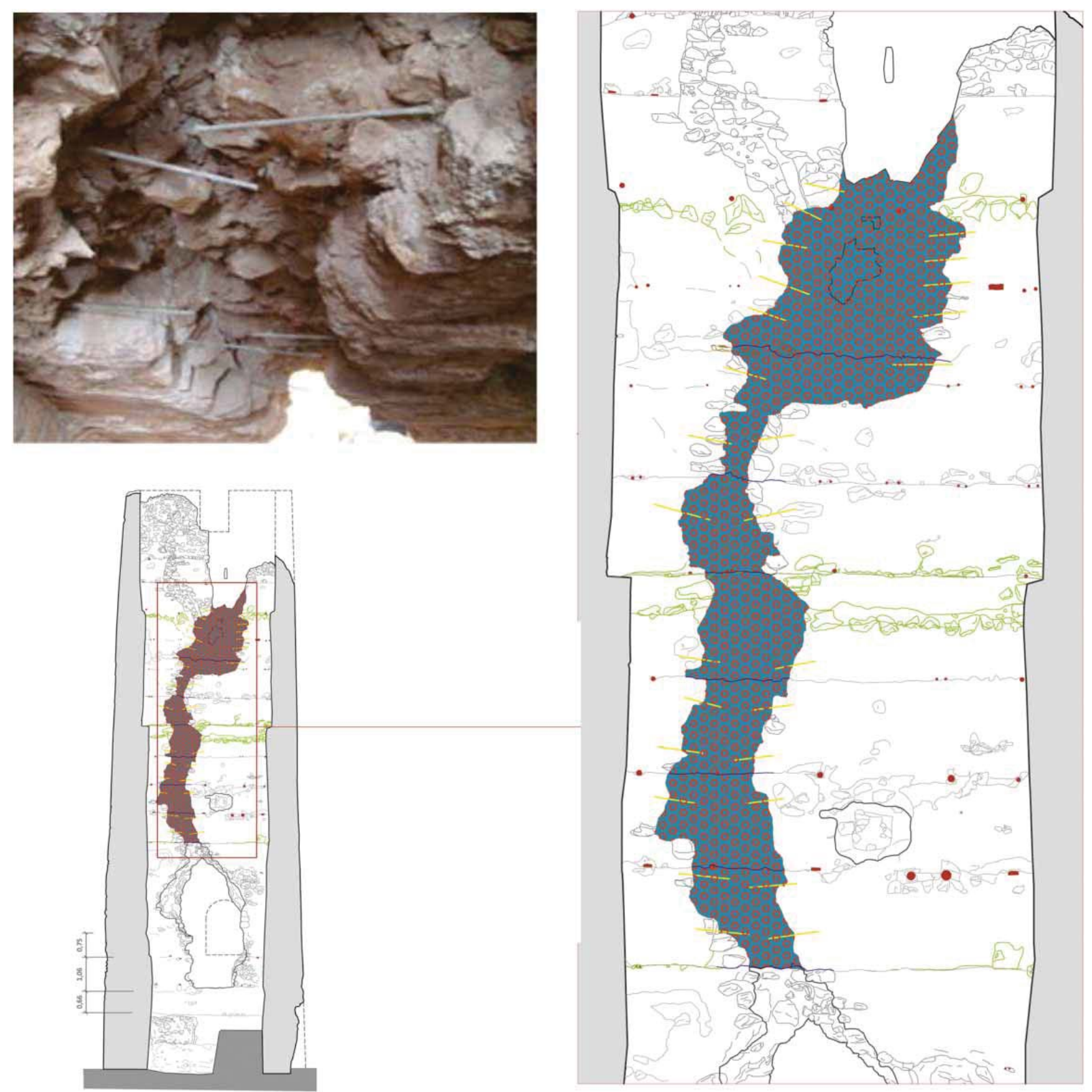

Figure 9. Reintegration of the lacunae, with the insertion of corrugated fibreglass rods to guarantee the connexion of the historic fabrics and the added mass (Vegas \& Mileto).

The excavation of the tower environs and the finding of remains from the Islamic settlement initially carried out in the 1980s were completed by approaching a bigger area, which led to the discovery of the ancient lime kiln. The value of this ensemble was enhanced and explicative signs were placed to support the understanding of this building and the old arrangement of the village. At present the archaeological site receives guided tours of groups of people who are interested in learning about its Islamic background of the place.

\section{Conclusions}

The study prior to the preservation of the Bofilla tower, together with the study of the traces of the building work and traces of the tower's use throughout the centuries printed on the fabric of the rammed earth, has allowed us to unveil the design and construction secrets that have enabled the tower's survival for 800 years, even though in many of these it was abandoned 
and fell prey to weather damage. The preservation of the rammed earth architecture carried out with earth and a small amount of lime was an important challenge for the discipline. The challenge faced during the preservation process was, on the one hand, to conciliate the needs derived from the progressive degradation of the tower with the peculiarity of its material and constructive technique, ${ }^{13}$ and, on the other, the need to preserve historic and cultural authenticity and respect its original materials and construction procedures while meeting the requirements of compatibility, distinguishability, reversibility and durability of the intervention in order to preserve the character of the building.

The preservation was awarded the Outstanding Earthen Architecture in Europe Label 2011, the Premio Internazionale Domus Restauro e Conservazione 2012 and a Europa Nostra 2013 Accesit.

\section{Notes on contributors}

Fernando Vegas, architect (1990) and professor at the Universtat Politècnica of València (Spain), teaches architectural critics and conservation both in graduate and postgraduate courses. He has been a guest lecturer in the universities of Venice and Palermo (Italy), Cordoba (Argentina) and Pennsylvania (USA). He is co-director of the journal Loggia and the UNESCO Chair for Earthen Architecture in Spain and has extensively published on conservation. His main research interests are architectural conservation, traditional techniques and history of nineteenth century architecture.

Camilla Mileto, architect (1998) and professor at the Universitat Politècnica of València (Spain), teaches architectural conservation both in graduate and postgraduate courses. She has been a guest lecturer in the universities of Venice (Italy), Cordoba (Argentina) and Pennsylvania (USA). She is co-director of the journal Loggia and the UNESCO Chair for Earthen Architecture in Spain and has extensively published on conservation. Her main research interests are conservation of traditional architecture, especially earthen architecture, both from a theoretical and practical point of view.

Maria Diodato studied architecture at the University of Trieste (Italy). She is presently finishing her PhD studies at the Universitat Politècnica of València on the research of traditional floor and roof structure in the city of Valencia under the supervision of Professors Camilla Mileto and Fernando Vegas. Her main research interests are the study of material built culture and the conservation of the structure of traditional architecture.

\section{Notes}

1. Camilla Mileto, Fernando Vegas, and Valentina Cristini, 'Earthen Architecture in Spain', in Terra Europae, Earthen Architecture in European Union (Pisa: ETS, 2011), 181-185.

2. André Bazzana and Pierre Guichard, 'Les tours de defense de la huerta de Valence au XIII s', Mélanges de la Casa Velázquez XIV (1978): 73-106.

3. Pablo Rodríguez, La torre árabe observatorio en tierras valencianas. Tipología arquitectónica (unpublished thesis, UPV, Valencia, 2008).

4. Pedro López Elum, La alqueria islamica en Valencia. Estudio arqueológico de Bofilla, siglos XI a XIV (Valencia: Generalitat, 1994), 42-45.

5. José Burriell and Luisa Ruiz, Informe arqueológico (unpublished dossier, Ayto Betera, Valencia, 2009).

6. Camilla Mileto and Fernando Vegas, 'Reflections about the Restoration of a Rammed Earth Islamic Tower', in Rammed Earth Conservation (London: Balkema, 2012), 387-392.

7. Stefan Kroner, Laura Osete, and María Teresa Doménech, Informe analítico LMP 37_09. IRP/UPV (unpublished dossier, UPV, Valencia, 2009): 12.

8. Nicola Macchioni, Informe de caracterización de la madera empleada en Torre Bofilla (unpublished dossier, Firenze, CNR-IVALSA, 2009).

9. Camilla Mileto, Fernando Vegas, Valentina Cristini, and Lidia García Soriano, 'Restoration of Rammed Earth Architecture in the Iberian Peninsula: Ongoing Research', in Rammed Earth Conservation (London: Balkema, 2012): 381-386. 
10. Camilla Mileto et al., La restauración de la arquitectura de tapia en la Península Ibérica. Criterios, técnicas, resultados y perspectivas (Research Project. MICIIN, Madrid, ref. BIA 2010-18921, 2010).

11. Camilla Mileto, Fernando Vegas, and José Manuel López Osorio, 'Criteria and Intervention Techniques in Rammed Earth Structures. The Restoration of Bofilla Tower at Bétera (Valencia)', Informes de la Construcción 63, no. 523 (2011): 81-96.

12. Tiziana Serena and Guido Zucconi, Camillo Boito. Un protagonista dell'Ottocento Italiano (Venezia: IVSLA, 2002).

13. John Warren, Earthen Architecture: The Conservation of Brick and Earth Structures (London: Butterworth-Heinemann, 1999), 10.

14. René Guérin (ed), Outstanding Earthen Architecture in Europe. Award 2011 (Vaucluse: CAUE 2011), 27. Francesco Guidi \& Chiara Nardelli, "International character of Fassa Bartolo Restoration and Conservation Award", Paessaggio Urbano 2 (2012): 8-17. 